\title{
ECO LEARNING AND HANDICRAFT PLASTIC TRASH TO EDUCATE CHILDREN IN TAMBAK LOROK VILLAGE, SEMARANG
}

\author{
Dewi Sawitri ${ }^{1}$, Ihdayani Banun Afa $^{2}$, Tri Yuliyanti ${ }^{3}$, Deni Faizal Zulang Riyadi ${ }^{4}$, \\ Imam Setyawan ${ }^{5}$ \\ dewisawitri7@gmail.com ${ }^{1}$ \\ Psychology, Faculty of Psychology, Diponegoro University ${ }^{1,5}$ \\ Statistics, Faculty of Science and Mathematics, Diponegoro University ${ }^{2}$ \\ Chemistry, Faculty of Science and Mathematics, Diponegoro University ${ }^{3}$ \\ Mechanical Engineering, Faculty of Engineering, Diponegoro University ${ }^{4}$
}

\begin{abstract}
Tambak Lorok is one of the coastal areas in Semarang city which is located along the Banger River, Tanjung Mas district. Tambak Lorok environment is included as a dirty and improper environment for habitation due to the high amount of stingy trash. In fact, the use of plastic and bottle plastic is constantly increasing from year to year. As result, this certainly causes complex problems for both prevention and handling. Because of its characteristic which is difficult to be decomposed by natural decomposer, plastics become the most common and dangerous soil polutor. Using the plastic trash become handcraft is an effort to minimize the disposal of plastics and to save energy resources in a certain extent and to reduce the dependency of imported raw materials. Utilization of plastic trash on a household scale can be done by reusing plastic trash for different purposes, e.g. wall paint places which is made from plastics can be used for piggy bank, verticulture or pencil case. This handicraft from plastic trash is intended for 22 elementary school children in Tambak Lorok village. It can enable them to develop their creativity as well as to have awareness in maintaining environmental hygiene in order to realize Tambak lorok as a marine tourism spot and to support government program for Indonesia free of waste in 2020. Environmental education (eco learning) is very important, especially to maintain the eco-system and environment of the community of Tambak Lorok. Therefore, we try to combine the application of environment-based learning and make handicraft to overcome the problems above. Environmental education by utilizing plastic trash thoroughly is expected to be a stimulus in empowering Tambak Lorok villager as a mean of awareness of the children to the environment and to assist the community in optimizing plastic trash so that people have the ability and potential in fostering environmental care and creative characters.
\end{abstract}

Keywords: Eco learning; Handicraft Plastic Trash; Utilization trash. 


\section{INTRODUCTION}

Tambak Lorok village in Tanjung Mas, North Semarang is a coastal village located in the Java Sea and crossed by Banger River ${ }^{1}$. This village known as a fishing village since 1950. In the new Orde this village included in the IMPRES Villages (IDT) with relatively dirty environment and low education. Tanjung Mas also be the most of the waste in the district north of Semarang. The Trash generated of plastic waste, industrial waste and marine litter. Trash is a material or substance, both organic and inorganic generated from any human activity. Activity in question can be a household activity, industrial, and commercial activities ${ }^{2}$.

Conditions of education in Tambak Lorok is still low, especially related to trash, it make us hold an eco learning activities. Eco learning is an educational effort to implement programs based on the environment ${ }^{3}$. Early education of children to be one effective way to solve the problem, so targeted in our program are children. This early education is a fundamental influence on the development of next child up to adults ${ }^{4}$. This was confirmed that the early years of a child's life is a fundamental and likely to persist and affect the attitudes and behavior of children throughout his life ${ }^{5}$. Education to making handicraft from plastic trash has also become a way to reduce the amount of trash in the Tambak Lorok village. Besides, functioning as a developer of children's creativity. One of the potential of the child is creativity. Early childhood creativity can be developed through play, this is reinforced by showing a close relationship between playfulness and creativity ${ }^{6}$ In addition, the play leads development ${ }^{7}$ It became our basic priority system. fun learning in the learning. Environmental education is particularly important to keep marine ecosystems in view of a government program that will make the region Tambak Lorok as maritime tourism and support the Government in achieving waste-free Indonesia 2020.

\section{METHOD}

The method which used in this activities is Pre-Eksperimental design with one group pretest post-test design. Research is designed by looking at the first ability of subject (pretest). Furthermore, subjects treated using eco learning activities, then do the final measurement (post-test) ${ }^{8}$. Total sample are 20 children. It's conducted in March - June 2017 at Tambak Lorok, Semarang. There consists of three stages during the program:

a. Early preparation

Preparation of initialise to carry out pre-programmed prior to the activity. Among them pre-program survey the location, volunteer recruitment, know the understanding of the 
target through a pre-test and adjust programs / activities according to the needs of the target.

b. Implementation of eco learning activities

Implementation or treatment is done with eco learning activities through fun learning (video, storytelling and games) and direct practice. Do every week in a reading house and along the coast of Tambak Lorok village.

The group divided into 4, which is done by grouping children 5-6. In each group will be given a sister companion (volunteer). Their companion in this group to provide more knowledge to children so that children quickly receive the learning.

\section{a. Making a Handicraft from Plastic Trash}

ingredients. Plastic trash such as bottles, bottle caps, straws, glue, double-sided tape, paper cutter, rubber nipples, skewers and pencil.

Procedure. Children are invited to stroll around the neighborhood as he was told the impact of waste and the important of handicraft (reuse trash) to reduce the amount of waste in the environment around them. Then, the children were divided into 4 groups. Each group consists of 5-6 children accompanied by a sister companion. In each group tasked with making different creations that air piggy bank for the first group, a pencil holder for the second group, toy cars for the third group and the vase and flowers of crackle u fourth group. Sister escort duty told and directed on how to manufacture trash creations in the group.

\section{b. Making Verticulture from a Unused Bottles}

ingredients. Large-size plastic bottles of 1.5 liters, cap bottles, containers of used paint, scissors, cutter, rope or wire, paint, brush, old newspapers on board.

Procedure. Children are invited to clean the bottles with water flowing. Once clean, dried with a cloth, cut to fit the shape of verticulture to be made and painted with white benthic using paint by sister companion. The bottle was painted then allowed aerated briefly. While waiting for the paint to dry the children gathered for verticulture let on how to manufacture and divided into 4 groups. The division of the group consists of 5-6 children. In each group, was commissioned to decorate the bottle that has been adapted to verticulture with a brush and paint. After decorating the bottles and the paint is dry, the children are invited to plant crops to container that has been decorated and stringing verticulture to hang next to the fence of the house. 
c. Trash Pick Movement ingredients. Garbage bag

Procedure Children are invited to stroll around the neighborhood. Seeing how it will affect garbage and pollute the environment so that it looks unsightly. Children were then invited to pick up the garbage and throw trash and notified place further impacts associated waste that is not processed correctly.

\section{c. Evaluation}

Evaluation is done at the end of the activities by a team of community service accompanied by a supervisor. Evaluation is done by post-test activities and interview the children, sister companion (volunteer activities), and Tambak Lorok partners.

\section{RESULTS AND DISCUSSION}

\section{a. Volunteer}

Volunteer in this activity are 5 people accompanied by one adviser. Recruited by open recruitment system to the interview. Volunteer task is to accompany the children during the activities and continued the Eco Learning Trash.

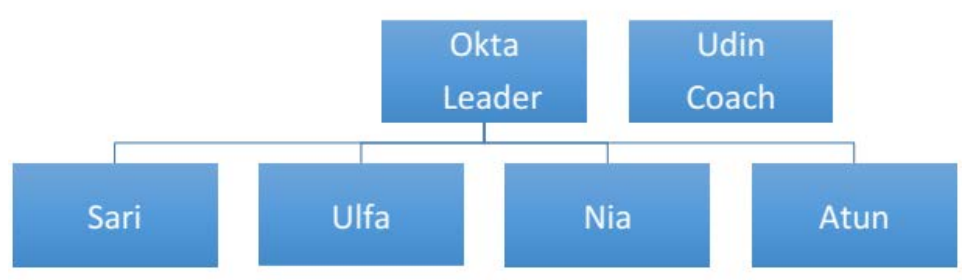

\section{b. Eco Learning Trash}

The purpose of this study aims to know the effectiveness of Eco Learning and Handicraft activity to educate children about how to caring the environment.. The program is designed to introduce trash in children aged 6-

11 years. Introduction of rubbish bins provided include definition, types of waste (organic and inorganic), the impact of waste on the environment and how to solve problems related to garbage. With the introduction of litter can understand the importance of protecting the environment through the behavior 
of the little things that start from oneself, such as reducing the use of goods which led to trash, reusing items can still be used, and recycling waste.

The process of introduction of garbage is done through lectures, fun learning (fairy tales, videos, games) and direct practice. Selection of this method to make children enthusiastic to learn about the garbage, because in addition to learning in a fun way, children can look directly related to the environmental conditions and the impact of garbage from the garbage. Children are also becoming active in asking, questioning, creative, devote attention / concentration in the atmosphere of learning that lead to comfort for the child so that the learning process can be optimally achieved with the development potential of children ${ }^{9}$.

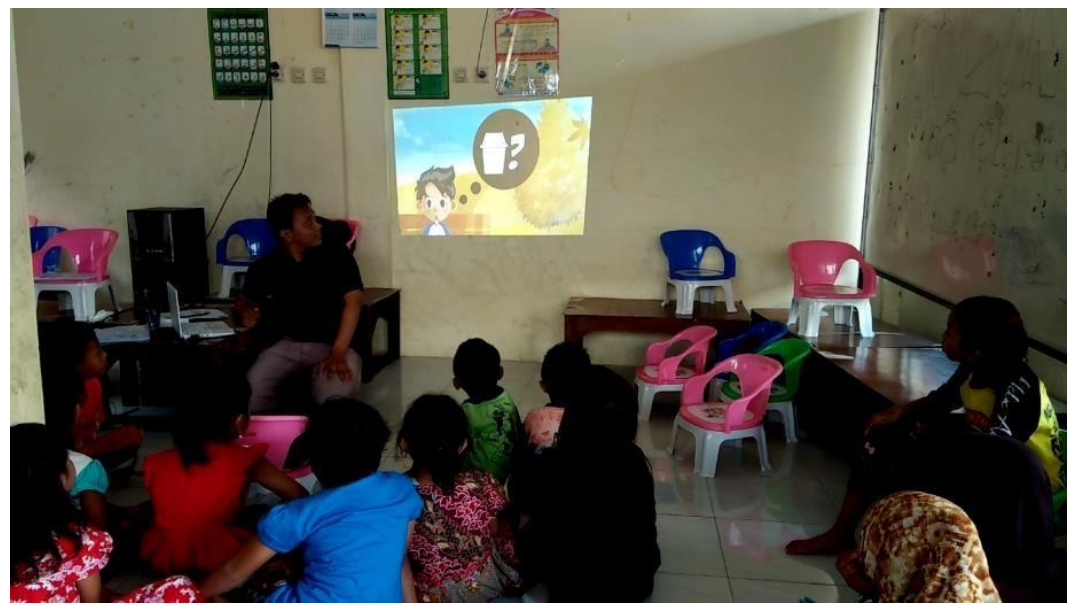

\section{Figure 1. Eco Learning Trash c. Manufacture Creations Plastic Waste}

process of making creations junk made by children accompanied by sister companion produces several craft is, piggy banks from plastic bottles, flower of crackle, pencil, toy cars and pot verticulture were then planted with seedlings of ornamental plants. This meant that children have the creativity in the use of waste in the surrounding neighborhood into goods which have use value. In addition, the activity of making this trash creations as well as a crucial step in reducing the amount of plastic waste. A target of the Indonesian government to achieve waste-free in 2020, making the waste management sector plays a fundamental role. This has become a priority programs to develop children role in reducing the harmful effect of plastic waste. 


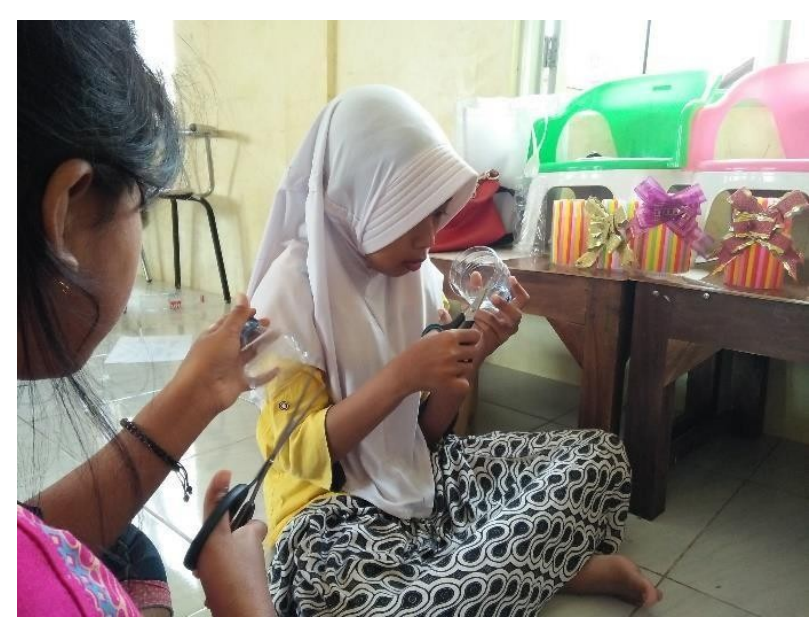

Figure 2. Create Training Plastic Waste

\section{d. Trash Pick movement}

Adoptee movement of waste is a real action to take the children pick up the trash that was in the neighborhood. This movement is held every Sunday afternoon around Tambak Lorok. Children are invited to walk while picking up trash are still scattered and explained the importance of keeping the environment free of litter. It is to realize the culture of safeguarding the environment and inculcate good habits to dispose of waste in place.

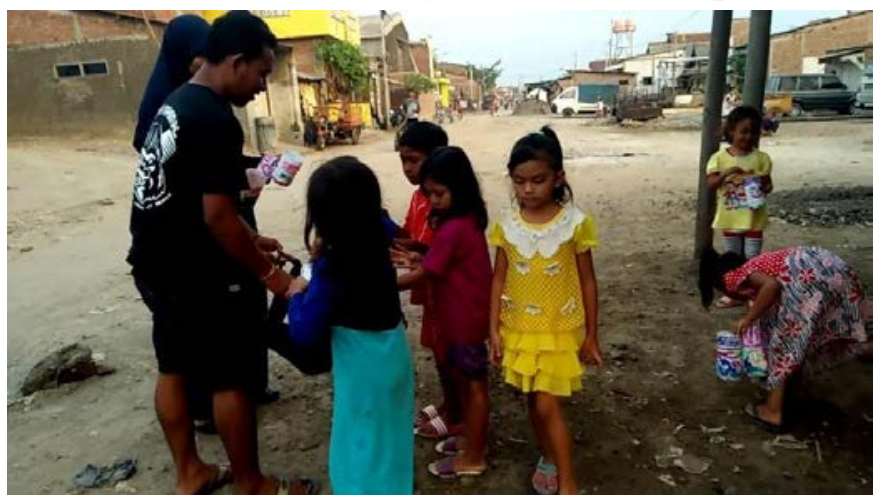

Figure 3. Movement of Waste Pick

\section{e. Handicraft Plastic Trash Display}

This is an exhibition of various creations that have been made by children. This activity is an appreciation of the willingness of children in the creation of waste into a product that has a use value, as well as introducing the public that trash can be used again. In addition to the trash creation display is displayed guidebooks and tips to overcome problems related to garbage. 
This is the top event in which the implementation was also held competitions, selection ambassador and symbolic handover of Eco Learning Books trash to volunteer for the sustainability of the program.
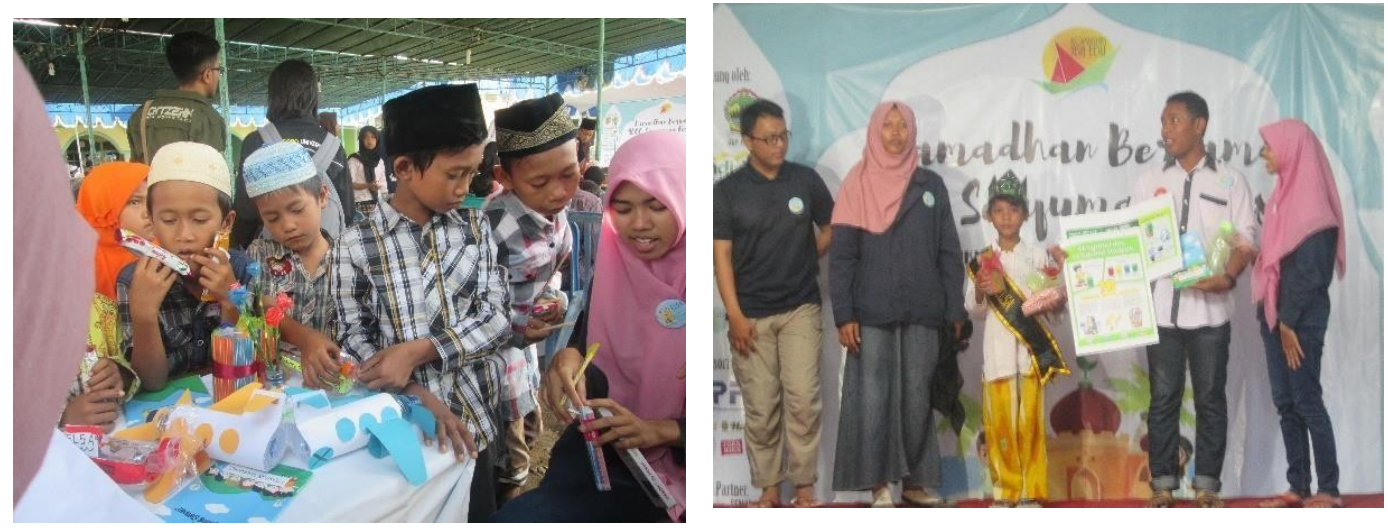

Figure 4. Trash Creation Display f. Program Success Rate

The success of this activities seen from the increase in children's knowledge about the importance of protecting the environment from plastic waste are seen from the pre-test and post-test. Statistical methods used in this research that Test Paired Sample T-Test with the following hypotheses:

Hypothesis:

$\mathrm{H}_{0}$ :There is no significant increase in the children's knowledge about the importance of protecting the environment from plastic waste before and after the service programs executed $\mathrm{H}_{1}$ :There is a significant increase in children's knowledge about the importance of protecting the environment from plastic waste before and after the dedication program implemented

Rejection Criteria: $\mathrm{H}_{0}$ is rejected if sig. (2-tailed) $<\alpha=5 \%$ 


\section{Paired Samples Test}

\begin{tabular}{|c|c|c|c|c|c|c|c|c|}
\hline \multirow[b]{4}{*}{ Pair 1 before - after } & \multicolumn{5}{|c|}{ Paired Differences } & & & Sig. (2-tailed) \\
\hline & \multirow{2}{*}{\multicolumn{2}{|c|}{$\begin{array}{l}\text { Std. } \\
\text { Deviation }\end{array}$}} & $\begin{array}{c}\text { Std. Error } \\
\text { Mean }\end{array}$ & $\begin{array}{l}95 \% \\
\text { Interval }\end{array}$ & $\begin{array}{l}\text { Confidence } \\
\text { of the }\end{array}$ & & & \\
\hline & & & & Lower & Upper & & & \\
\hline & $\begin{array}{l}2.3433 \\
6 \\
49961\end{array}$ & & & -1.59091 & -.55192 & -3184 & 21 & .004 \\
\hline
\end{tabular}

From the calculations by SPSS 16 . obtained sig. (2-tailed) $=0.004>0.05(\alpha)$ then $\mathrm{H}_{0}$ is rejected and accept $\mathrm{H}_{1}$ means there is a significant increase in children's knowledge about the importance of protecting the environment from plastic waste before and after the dedication program implemented.

\section{CONCLUSION}

The program that has been running for 4 months are eco learning activities, the manufacture of handicraft plastic trash and planting of seedlings, the movement of garbage collected trash handicraft and Trash Handicraft Display. This activities increase the children's knowledge about the importance of protecting the environment from plastic waste before and after the treatment or implementation. It showing the creativity and knowledge of children associated trash go up. The children began to throw trash in the trash bin by differentiating types of waste, may apply creations manufacture garbage and picking up trash participate making the environment around Tambak Lorok be cleaner. This activity will be followed by volunteers with periodic monitoring of eco builder garbage learning and community service teams. The suggestion of this service program is the sustainability of the program to be thorough. 


\section{REFERENCES}

Wulanningrum SD \& Theresia Budi Jayanti. 2016. "Evaluation of Existing Condition Pond.

Region Lorok To Implement Minapolitan Concept," Journal of Urban Development Volume 4 No. 1 (21-28).

Notoatmodjo S. 2002. Health Research Methods. Jakarta: Rineka Reserved.

Kasabov, Nikola. Ecos 1996: Evolving Connectionist Systems And The Eco Learning Paradigm. The MIT Press, CA, MA.

Priyanto, Aris. 2014. "Creativity Development In Early Childhood Through Play Activities". Scientific journal Master "COPE" No. 02.

Hurlock, Elizabeth B. Developmental Psychology, Istiwidayanti translation and Soejarwo. Jakarta: Erland, 1999

Munandar, Utami SC (1992). Developing Talent and Creativity SchoolChildren.Jakarta: PT Grasindo

Hartati, S. (2005). Developments in Early ChildhoodLearning. Education Ministry Director General Higher Education. Jakarta

Sugiyono. (2013). Metode Penelitian Kuantitatif Kualitatif dan R\&D. Jakarta : Rajawali. Trinova, Z. (2011). Itself Learn and Play Fun for Students. Al-Ta'lim Journal, 3.209-215 
